\title{
Numerical investigation of injection parameters and piston bowl geometries on emission and thermal performance of DI diesel engine
}

\author{
Ikhtedar Husain Rizvi ${ }^{1} \cdot$ Rajesh Gupta $^{1}$ \\ Received: 14 November 2020 / Accepted: 4 May 2021 \\ Published online: 12 May 2021 \\ (c) The Author(s) 2021 \\ OPEN
}

\begin{abstract}
Tightening noose on engine emission norms compelled manufacturers globally to design engines with low emission specially $\mathrm{NO}_{x}$ and soot without compromising their performance. Amongst various parameters, shape of piston bowls, injection pressure and nozzle diameter are known to have significant influence over the thermal performance and emission emanating from the engine. This paper investigates the combined effect of fuel injection parameters such as pressure at which fuel is injected and the injection nozzle size along with shape of piston bowl on engine emission and performance. Numerical simulation is carried out using one cylinder naturally aspirated diesel engine using AVL FIRE commercial code. Three geometries of piston bowls with different tumble and swirl characteristics are considered while maintaining the volume of piston bowl, compression ratio, engine speed and fuel injected mass constant along with equal number of variations for injection nozzle size and pressures for this analysis. The investigation corroborates that high swirl and large turbulence kinetic energy (TKE) are crucial for better combustion. TKE and equivalence ratio also increased as the injection pressure increases during the injection period, hence, enhances combustion and reduces soot formation. Increase in nozzle diameter produces higher TKE and equivalence ratio, while $\mathrm{CO}$ and soot emission are found to be decreasing and $\mathrm{NO}_{x}$ formation to be increasing. Further, optimization is carried out for twenty-seven cases created by combining fuel injection parameters and piston bowl geometries. The case $D 2 H 1 P 1\left(H_{1}=0.2 \mathrm{~mm}, P_{1}=200\right.$ bar $)$ found to be an optimum case because of its lowest emission level with slightly better performance.
\end{abstract}

Keywords AVL FIRE · Injection pressure · Nozzle size · Piston bowl shape

\section{Introduction}

In the wake of stringent emission regulations and rapid depletion of fossil fuel reserves, production of fuel efficient compression ignition engines with low emission has become extremely challenging task for engine manufacturers around the world today. The governing bodies are increasingly succumbing to pressure from the threats of environmentalists and on the other hand, growing demand for higher fuel efficiency is driven by greater industrialization and dwindling natural energy resources. With enforcement of the Euro VI standards, achieving $\mathrm{NO}_{x}$ levels lower than $0.3 \mathrm{~g} / \mathrm{kWh}$ has compelled researchers to accelerate efforts for greater technological advancements and evolve comprehensive optimization design techniques. Further, greater legislations on $\mathrm{CO}_{2}$ emission may not be ruled out in the near future. The handling of all such mutually competing issues complicates the engine design and necessitates thorough understanding of diesel engines and their mechanism specially the process of fuel combustion. The fuel combustion inside the combustion chamber is a fusion of various intricate processes, and it mainly hinges on formation of adequate fuel and air mixture. The formation of mixture essentially involves

Ikhtedar Husain Rizvi, ikhtedar.husain@gmail.com | 'Department of Mechanical Engineering, MANIT, Bhopal, India. 
various issues such as fuel-air interaction, fuel atomization, evaporation of fuel droplets, collision with cylinder walls and other surfaces, rupture of fuel droplets with the boundaries and their speed, energy and mass exchange. In order to reduce exhaust emission and achieve better engine performance necessitates comprehension of all intricate details of piston bowl geometry, dynamics of fuel-air mixture and how these parameters affect the combustion process. Höök and Tang [1] presented a review of fossil fuels depletion and climate change; fossil fuels were the major source of $\mathrm{CO}_{2}$ emission which resulted in global temperature rise. The problem of fossil fuel depletion and the problem of anthropogenic climate change were closely linked with each other and both the issues should be addressed simultaneously.

Gafoor and Gupta [2] performed numerical study on the effects of piston bowl shape and swirl ratio on exhaust emanating from diesel engines and concluded that reduction in piston bowl diameter led to increase $\mathrm{NO}_{x}$ formation and reduced soot during combustion because of high combustion rate. Jafarmadar et al. [3] examined the effects of combustion chamber geometries on the emission formation and on the performance of engine. It was deduced that the higher bowl depth created stronger squish pressure and increased power output of the engine. Whereas a higher radius of the piston bowl produced higher swirl leads to soot reduction. Corcicone et al. [4] noted that reentrant combustion chamber with elevated TKE and air velocity during fuel injection yielded the excellent results and lowers the smoke emission. Montajirn et al. [5] investigated the spray behaviour over a re-entrant piston cavity of the round lip and a simple cylindrical shape. It was concluded that for DI diesel engine having re-entrant piston cavity of the round lip resulted enhancement of spread of fuel spray and its volume, and subsequently, better fuel-air mixture is formed. Khan et al. [6] deliberated the influence of piston bowl shape and spray pattern on mixing, combustion and emission characteristics of a diesel engine and found that the toroidal combustion chamber generated a strong squish, turbulence and thus resulted in upgraded mixture of air and fuel. It was observed that air motion and spray angle significantly influenced the process of fuel-air mixture preparation and consequently the combustion process and emission characteristics. Fuel sprayed up to an angle $165^{\circ}$ was appropriate, however fuel sprayed at $160^{\circ}$ showed the excellent results. Fuel spray greater than $165^{\circ}$ showed detrimental effects to the engine as the spray directed mostly in the squish region. Risi et al. [7] employed an optimization methodology for different geometries of the combustion chamber and spray injection angle. For lower $\mathrm{NO}_{x}$ emission, narrow and deep combustion chamber with shallow re-entrance was recommended in which the spray should be directed towards bowl entrance. Rakopoulos et al. [8] presented the comparison of the results of quasi-dimensional model and of CFD model to analyse the influence of piston bowl shape and engine rotations on a DI diesel engine and culminated that predictions of both models are identical. Lim et al. [9] conducted 3D CFD simulation to study the influence of piston bowl geometry and spray angle on the particulate matter emanating from diesel engine. It was concluded that the soot emission and wall impingement were reduced with the modification of piston bowl geometry and spray angle. Wei et al. [10] established initial swirl impact on the in-cylinder air flow by observing the effect of various swirl ratios ranging from 0.2 to 3.2. Gan et al. [11] conducted an experimental study on injection timing and initial swirl ratio affecting emission formation and engine performance of a direct injection diesel engine. It conjectured that the rich air-fuel mixture spots in the cylinder can be reduced by increasing initial swirl ratio. Perini et al. [12] carried numerical study of in-cylinder flow on single cylinder diesel engine, and the results showed that combustion simulations were helpful to understand the spray flow field at the time of combustion. Torregrosa et al. [13] analysed combustion noise and emission formation by compression ignition engine fuelled with premixed charge and deduced that the knock generation mainly depended on mixture formation and phase of combustion which could damage the cylinder walls and piston of the engine. Benajes et al. [14] studied the process of $\mathrm{NO}_{\mathrm{x}}$ formation in a diesel engine and observed that the formation of $\mathrm{NO}$ depends on slow or poor combustion. It was concluded that high amount of EGR mass fraction also increases NO formation in a high speed diesel engine. Jayashankara et al. [15] studied the intake pressure and engine timing effects on emission and performance of diesel engine. It was culminated that supercharging with inter-cooling enhanced the engine performance and augmented $\mathrm{NO}_{x}$ formation. Abedin et al. [16] used vegetable oil and biodiesel in diesel engine and studied its effect on emission formation. It was concluded that the performance was good but $\mathrm{NO}_{x}$ emission increased because of the high temperature of combustion. Ozer [17] reported that the blend of biodiesel and waste cooking oil in diesel engine and examined the effect on emission and performance characteristic. It was concluded that the $\mathrm{NO}_{\mathrm{x}}$ formation increased with an increase in the amount of biodiesel in the mixture. Chandran et al. [18] compared results of numerical simulation with the experimental results of DI diesel engine by considering the blend of distilled waste plastic oil and diesel as alternate fuel. This Study revealed that the simulation of the ratio of $70 \%$ diesel and $30 \%$ distilled waste plastic oil found to has $\mathrm{NO}_{x}$ and SOOT higher by $7 \%$ and $16 \%$, respectively, than conventional diesel in simulation while the value of $\mathrm{NO}_{x}$ and SOOT was lesser by 
$16 \%$ and $17 \%$, respectively, than the experimental value of the blended fuel. Kumar et al. [19] used Solketal with Soyabean biodiesel in the proportion $9 \%, 10 \%, 12 \%$ and $15 \%$ by volume to appraise the performance and emission of diesel engine at $50 \%$ load condition. Study revealed that $\mathrm{CO}$ and total hydro carbon (THC) emission reduced by increasing solketal percentage while the $\mathrm{NO}_{x}, \mathrm{CO}_{2}$ and BSFC increased as compared to those with pure diesel. Kumara et al. [20] investigated performance and emission of DI diesel engine by adding di-tert butyl peroxide (DTBP) as an additive in fuel where $40 \%$ diesel is replaced by hydrogen fuel. Brake thermal efficiency was found to increase as $87.5,14.68$ and $5.89 \%$ with 1,3 and $5 \%$ use of additive DTBP as opposed to the engine operating on pure diesel. $\mathrm{NO}_{x}$ and soot emission also decreased with the use of additive DTBP and hydrogen as secondary fuel. Hemanandh et al. [21] prepared a bio-fuel from the fish waste, slaughter waste of chicken and broiler excrete by pyrolysis process. This study revealed that the ratio of biofuel and diesel by volume 10:90 when used in diesel engine reduced emission of $\mathrm{CO}$ by $30.52 \%, \mathrm{HC}$ by $25.41 \%$ and $\mathrm{NO}_{\mathrm{x}}$ by $22.84 \%$. Along with this it also increased $\mathrm{CO}_{2}$ emission by $30.52 \%$ and $23.8 \%$ at $25 \%$ and $100 \%$ load, respectively. Viswanathan et al. [22] used fish oil ethyl ester (FOEE) with diesel in DI diesel engine. This study revealed that the use of FOEE reduces emission of $\mathrm{CO}, \mathrm{NO}$ and soot and preheating of FOEE by exhaust gas could further reduce emission level. Jaichandar et al. [23] performed experiments on biodiesel fuelled diesel engine and analysed the influence of fuel injection pressure and piston bowl shape. It was concluded that rise in injection pressure resulted in reduction of smoke and unburned hydrocarbon with increased $\mathrm{NO}_{x}$ due to better combustion. Agarwal et al. [24] examined the effects of pressure of fuel injection and timing of fuel injection over spray characteristic and particulate size number distribution using the fuel blend of Karanja biodiesel and pure diesel. The results demonstrated that higher penetration of spray tip and wider spray area were obtained with fuel injected at elevated pressures. Advancement the time of fuel injection resulted in increment of average particulate size. The lowest particulate number was obtained with $10 \%$ blend of biodiesel and diesel. Chinnamuthu et al. [25] varied fuel injection nozzle angle in the plane perpendicular to cylinder axis and considered angle of $30^{\circ}, 60^{\circ}$ and $90^{\circ}$. This study showed that angle $60^{\circ}$ nozzle yielded better emission and combustion characteristics because of higher turbulence produced by fuel spray. Fayad [26] investigated the effects of fuel injection strategies over the emission level of smoke and $\mathrm{NO}_{x}$ by varying timing of fuel injection at different load and engine speed by keeping design invariant. Experimental result showed that advancement in fuel injection resulted in reduction of $\mathrm{NO}_{x}$ and $\mathrm{BSFC}$. The similar results were also reported with low speed and high load. High fuel injection pressure reduced smoke exhaust. Kesharwani et al. [27] adopted multi-injection strategy for injection of fuel by injecting some portion of fuel prior to the main injection which created better combustion atmosphere for principal fuel injection. Pilot injection fuel mass was taken as 5, 10 and $15 \%$ by maintaining the total mass of fuel injected invariant. The case in which fuel mass kept as pilot injection is 5\%, and principal injection is $95 \%$ turned out as an optimum as soot and $\mathrm{NO}_{\mathrm{x}}$ emission reduced by $16 \%$ and $10 \%$, respectively, as compared to single injection. Wang et al. [28] employed a thermal barrier coating (TBC) to reduce the losses of heat from the inner side of the combustion chamber. The study revealed that the lower thermal conductivity and increased porosity of TBC resulted in 100-200 K high temperature into the combustion chamber yielding improved thermal efficiency and also higher temperature at exhaust improved after-treatment of outgoing gases to lower emission levels.

After comprehensive review of literature, it can be conjectured that there are studies undertaken to comprehend the effects of modifications to typical and toroidal combustion chamber geometries to improve performance and reduce emission. Further, a large number researcher also investigated the effects of injection parameter as well either conjunction with piston bowl geometrical variations with a view to identical objective. However, analysing the combined influence of typical combustion chamber geometry unlike the toroidal combustion chambers along with injection parameters is the subject of current research. The principal objective of the present analysis is to augment performance and minimise emission of a standard DI engine by combining variations in combustion chamber geometry and fuel injection parameters such as injection pressure and injection nozzle size. Three combustion chambers with different tumble and swirl ratios with three different injection pressures and three different nozzle diameters are chosen to comprehend the cumulative influence of these factors which are crucial to engine performance and emission control.

\section{Model descriptions}

In this study a four-stroke direct injection, single cylinder, naturally aspirated, water cooled diesel engine is considered. In all the simulations performed, piston bowl volume, compression ratio, engine speed and injected fuel mass are maintained constant so that results are purely based on the effect of fuel injection parameter and piston bowl geometry. Figure 1 shows the typical piston bowl design comprising of various parameters used for defining the 


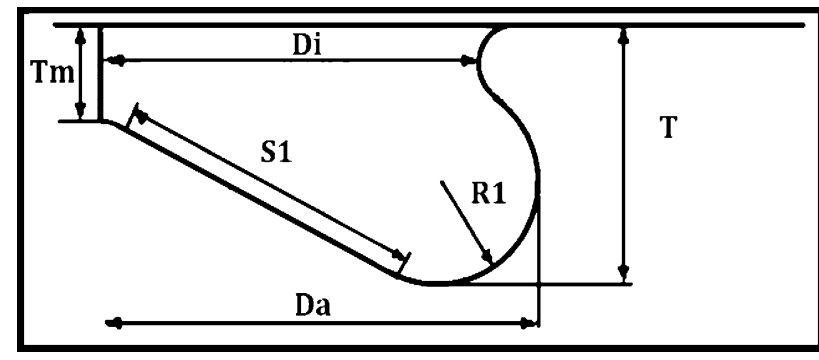

Fig. 1 TDC Typical outline of piston bowl geometry representing the main geometrical parameter

Table 1 Parameter defining the design of different piston bowl

\begin{tabular}{llll}
\hline Parameters & $D_{1}$ & $D_{2}$ & $D_{3}$ \\
\hline$T_{\mathrm{m}}(\mathrm{m})$ & 0.0058 & 0.00656 & 0.0049 \\
$D_{\mathrm{i}}(\mathrm{m})$ & 0.053 & 0.05031 & 0.058 \\
$D_{\mathrm{a}}(\mathrm{m})$ & 0.06 & 0.05622 & 0.06 \\
$T(\mathrm{~m})$ & 0.0175 & 0.01999 & 0.01564 \\
$R_{1}(\mathrm{~m})$ & 0.0065 & 0.00744 & 0.00475 \\
$S_{1}(\mathrm{~m})$ & 0.0201 & 0.01235 & 0.02223 \\
\hline
\end{tabular}
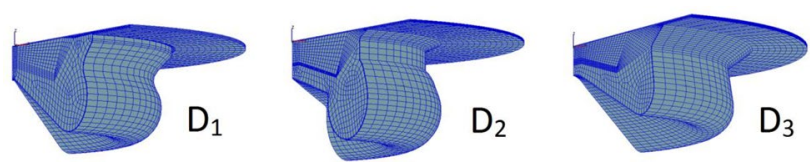

Fig. 2 Mesh distribution of three piston bowl geometries at TDC

Table 2 Geometrical specification and number of cells for different piston bowl

\begin{tabular}{llll}
\hline & Number of cells & Surface area $\left(\mathrm{m}^{2}\right)$ & Volume $\left(\mathrm{m}^{3}\right)$ \\
\hline$D_{1}$ & 32,480 & 0.00572 & $3.6314 \mathrm{e}^{-05}$ \\
$D_{2}$ & 32,156 & 0.00609 & $3.6314 \mathrm{e}^{-05}$ \\
$D_{3}$ & 32,252 & 0.00559 & $3.6314 \mathrm{e}^{-05}$ \\
\hline
\end{tabular}

geometry. Table 1 shows outline parameters for the three piston bowl designs. Figure 2 depicts the computational domain for three considered piston bowl design at TDC. The computational domains for each of the geometry $D_{1}$, $D_{2}$ and $D_{3}$ consist of only one-third of combustion chamber for the sake of symmetry. Table 2 shows the actual number of the cell used for numerical computations of corresponding piston geometries along with the bowl volume and surface area. It is evident that volume is constant, and the surface area is varied with the design of piston bowl geometry. Tables 3 and 4 show the engine specifications and initial and boundary conditions, respectively.
Table 3 Technical details of the engine

\begin{tabular}{ll}
\hline Engine & $\begin{array}{c}\text { 4-Stroke, single cylinder, } \\
\text { water cooled, diesel } \\
\text { engine }\end{array}$ \\
$\begin{array}{l}87.5 \mathrm{~mm} \\
\text { Cylinder bore }\end{array}$ & $110 \mathrm{~mm}$ \\
Stroke length & $234 \mathrm{~mm}$ \\
Connecting rod & 17.5 \\
Compression ratio & $1500 \mathrm{RPM}$ \\
Speed & $5.2 \mathrm{KW} @ 1500 \mathrm{RPM}$ \\
Power & 3 \\
No. of the nozzle hole & $0.2,0.25,0.3 \mathrm{~mm}$ \\
Nozzle outlet diameter & Direct injection \\
Type of injection & $23^{\circ}$ BTDC \\
Start of injection & $200,250,300 \mathrm{bar}$ \\
Injection pressure &
\end{tabular}

Table 4 Initial and boundary condition used for the numerical model

\begin{tabular}{ll}
\hline Cylinder head temperature & $425 \mathrm{~K}$ \\
Liner temperature & $375 \mathrm{~K}$ \\
Piston temperature & $525 \mathrm{~K}$ \\
Initial pressure & $1 \mathrm{bar}$ \\
Residual gas ratio & 0.05 \\
Initial temperature & $335 \mathrm{~K}$ \\
\hline
\end{tabular}

Simulations are carried out with inlet valve closing at $35.5^{\circ}$ crank angle (CA) after BDC and exhaust valve opening at $35.5^{\circ} \mathrm{CA}$ before BDC. Along with piston bowl geometries, three pressures of fuel injection (200 bar, 250 bar and 300 bar named as $P_{1}, P_{2}$ and $P_{3}$, respectively) and also three outlet diameter of fuel injecting nozzle $(0.2 \mathrm{~mm}, 0.25 \mathrm{~mm}$ and $0.3 \mathrm{~mm}$ named as $H_{1}, H_{2}$ and $H_{3}$, respectively) are taken for numerical simulations.

\section{Mesh independency study}

The mesh is generated using mesh generator tool of AVL Fire commercial software with active perpetual licence version 2013.1. Computational domain is discretised using structured hexahedron mesh. To determine the optimum mesh for onward computations, grid independence test was performed on three different grid sizes with numbers of cells as $14,052,30,428$ and 45,072 , respectively. The results are compared in terms of in-cylinder pressure against the crank angle. Figure 3 depicts that peak cylinder pressure variation at TDC for grid sizes of 14,052 and 30,428 cells is $6.1687 \%$, and variation between 30,428 and 45,072 cells is $0.2541 \%$. It can be deduced that further refinement of mesh from 30,428 cells to 45,072 cells, no appreciable variation in cylinder pressure, hence, 30,428 


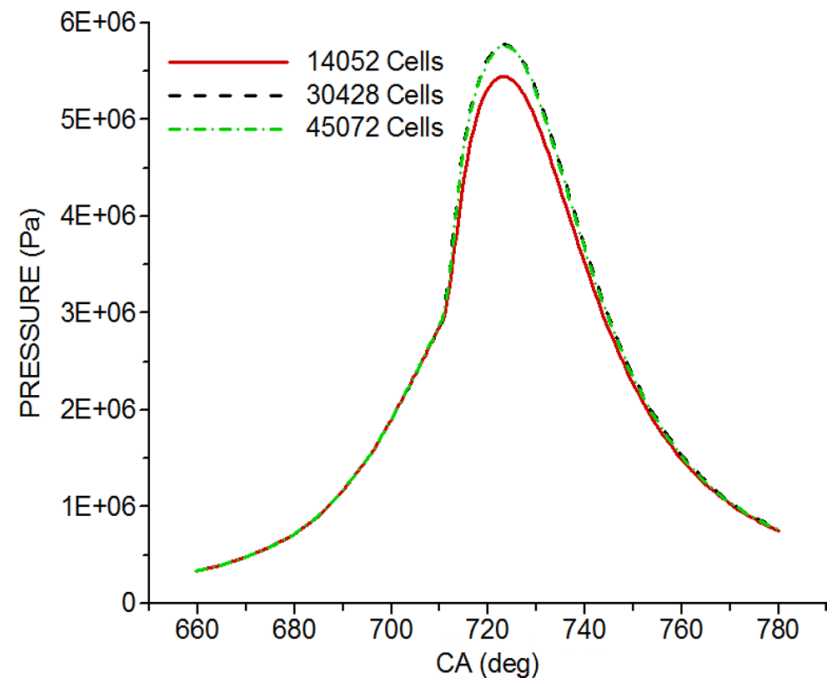

Fig. 3 Effect of grid resolution on the pressure curve

numbers of cells may be taken as optimum size for further simulations. For different piston bowl geometries, small variation in number of cells is permissible.

\section{The model validation}

In this study, the process of combustion occurring within the engine cylinder is numerically manifested using AVL FIRE which specially designed for modelling internal combustion engines. Various numerical models representing the physical and chemical processes during combustion are listed in Table 5. K- $\zeta-f$ model, developed by Hanjalic et al. [29], is used for modelling turbulence and turbulent heat transfer inside the combustion chamber. Fuel spraywall interaction model known as 'walljet 1' introduced by Reitz et al. [30] is used for the fuel particles striking wall of combustion chamber during the injection process. The spray breakup process is modelled by using the WAVE breakup model [31]. Dukowicz model [32] is being used for fuel spray droplet heating and evaporation. Extended

Table 5 sub-model used for simulation

\begin{tabular}{ll}
\hline Heat transfer wall & Standard wall function \\
Combustion & ECFM-3Z \\
Spray Breakup & WAVE \\
Wall interaction & Walljet 1 \\
Evaporation & Dukowicz \\
Turbulence & k- $\zeta-f$ \\
Soot model & Kinetic model \\
NO model & Extended Zeldovich \\
Wall treatment & Hybrid wall treatment
\end{tabular}

coherent flame model (ECFM-3Z) is used for modelling the diesel combustion process. This model manifests turbulent mixing, emission and flame spread. It can be used for both auto ignition and spark ignition engines simultaneously. Combustion model ECFM-3Z was described by Colin et al. [33]. Extended Zeldovich [34] model is used for $\mathrm{NO}_{x}$ formation during combustion. $\mathrm{NO}_{x}$ is formed during combustion at high temperature zone. A kinetic model is used for soot formation inside the combustion chamber. Soot formation is a complicated process, involving various reactions. Kinetic model of soot formation is described by Mauss et al. [35]. Since Tatschl et al. [36] performed validation of all the aforementioned numerical models. Evidently, this establishes the efficacy of the AVL FIRE code and, thus, separate validation is not necessary. However, case specific validation in the contest of the present investigation is obligatory.

Numerical simulation is carried out using the input parameter of the experimental condition at full load. For the validation of simulation results, predicted data of pressure curve and heat release curve are compared with experimental results of single cylinder DI diesel engine measured by Khan et al. [6]. Figures 4 and 5 show the simulation results indicating satisfactory agreement with the experimental data, hence, simulation process is adequately modelled.

\section{Results and discussion}

To examine the effects of piston bowl geometries and fuel injection parameter such as nozzle hole diameter and fuel injection pressure, twenty-seven number of cases were

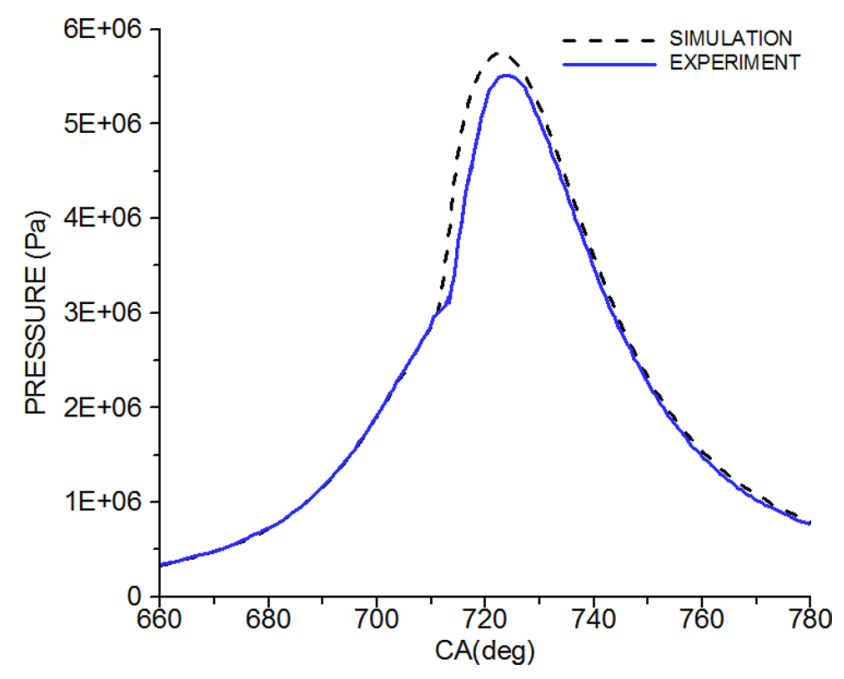

Fig. 4 Comparison of experimental and simulated result for in-cylinder pressure 


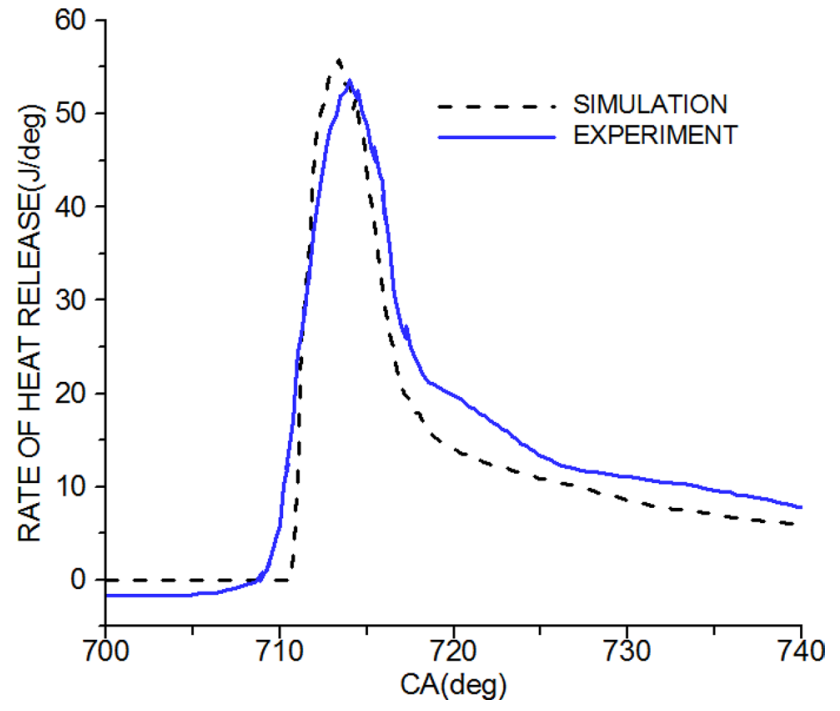

Fig. 5 Comparison of experimental and simulated results for the rate of heat release

Table 6 cases used for simulation

\begin{tabular}{lllll}
\hline Geometry & $\begin{array}{l}\text { Fuel injection } \\
\text { pressure (bar) }\end{array}$ & \multicolumn{3}{l}{ Nozzle outlet diameter $(\mathrm{mm})$} \\
\cline { 3 - 5 } & & $H_{1}=0.2$ & $H_{2}=0.25$ & $H_{3}=0.3$ \\
\hline$D_{1}$ & $P_{1}=200$ & $D_{1} P_{1} H_{1}$ & $D_{1} P_{1} H_{2}$ & $D_{1} P_{1} H_{3}$ \\
& $P_{2}=250$ & $D_{1} P_{2} H_{1}$ & $D_{1} P_{2} H_{2}$ & $D_{1} P_{2} H_{3}$ \\
& $P_{3}=300$ & $D_{1} P_{3} H_{1}$ & $D_{1} P_{3} H_{2}$ & $D_{1} P_{3} H_{3}$ \\
$D_{2}$ & $P_{1}=200$ & $D_{2} P_{1} H_{1}$ & $D_{2} P_{1} H_{2}$ & $D_{2} P_{1} H_{3}$ \\
& $P_{2}=250$ & $D_{2} P_{2} H_{1}$ & $D_{2} P_{2} H_{2}$ & $D_{2} P_{2} H_{3}$ \\
& $P_{3}=300$ & $D_{2} P_{3} H_{1}$ & $D_{2} P_{3} H_{2}$ & $D_{2} P_{3} H_{3}$ \\
$D_{3}$ & $P_{1}=200$ & $D_{3} P_{1} H_{1}$ & $D_{3} P_{1} H_{2}$ & $D_{3} P_{1} H_{3}$ \\
& $P_{2}=250$ & $D_{3} P_{2} H_{1}$ & $D_{3} P_{2} H_{2}$ & $D_{3} P_{2} H_{3}$ \\
& $P_{3}=300$ & $D_{3} P_{3} H_{1}$ & $D_{3} P_{3} H_{2}$ & $D_{3} P_{3} H_{3}$ \\
\hline
\end{tabular}

created by combining three nozzle outlet diameters, three fuel injection pressures and three piston bowl geometries as shown in Table 6.

\subsection{Effect of piston bowl geometry}

To analyse the effects of piston bowl geometry, three piston bowl geometries are considered with the same fuel injection pressure and nozzle outlet diameter. Figure 6 depicts turbulence kinetic energy and equivalence ratio distribution for considered piston bowl geometries. It can be observed that TKE is maximum for $D_{3}$ and minimum for $D_{1}$. Figure 7 shows the effects of piston bowl geometry on swirl ratio. The initial swirl ratio is unity for all cases. It can be observed that the swirl ratio value in the combustion chamber initially decreasing slightly this is because of wall friction and dissipation in the fluid due to turbulence. As the volume of combustion chamber decreases significantly, swirl magnitude increasing rapidly because of the moment of inertia of air mass and become maximum at TDC. After TDC it start decreasing because of volume expansion, wall friction and turbulence dissipation in the fluid. The depth of piston bowl $D_{2}(T=0.01999 \mathrm{~m})$ is highest among the all considered piston bowl which do not let air escape from piston bowl, hence produces highest swirl motion, and the depth of $D_{3}(T=0.01564)$ is least so that produces lower swirl motion into the combustion chamber. Figure 8 shows pressure and temperature variation for different piston bowl geometries. Pressure and temperature start increasing rapidly as the heat release starts from injected fuel. Highest peak pressure is obtained for bowl geometry $D_{1}$ and lowest peak pressure for $D_{3}$, however swirl ratio magnitude is maximum for $D_{2}$ but due to the large surface area of piston bowl heat
Fig. 6 Comparison between various piston bowl geometries in terms of turbulence kinetic energy and equivalence ratio

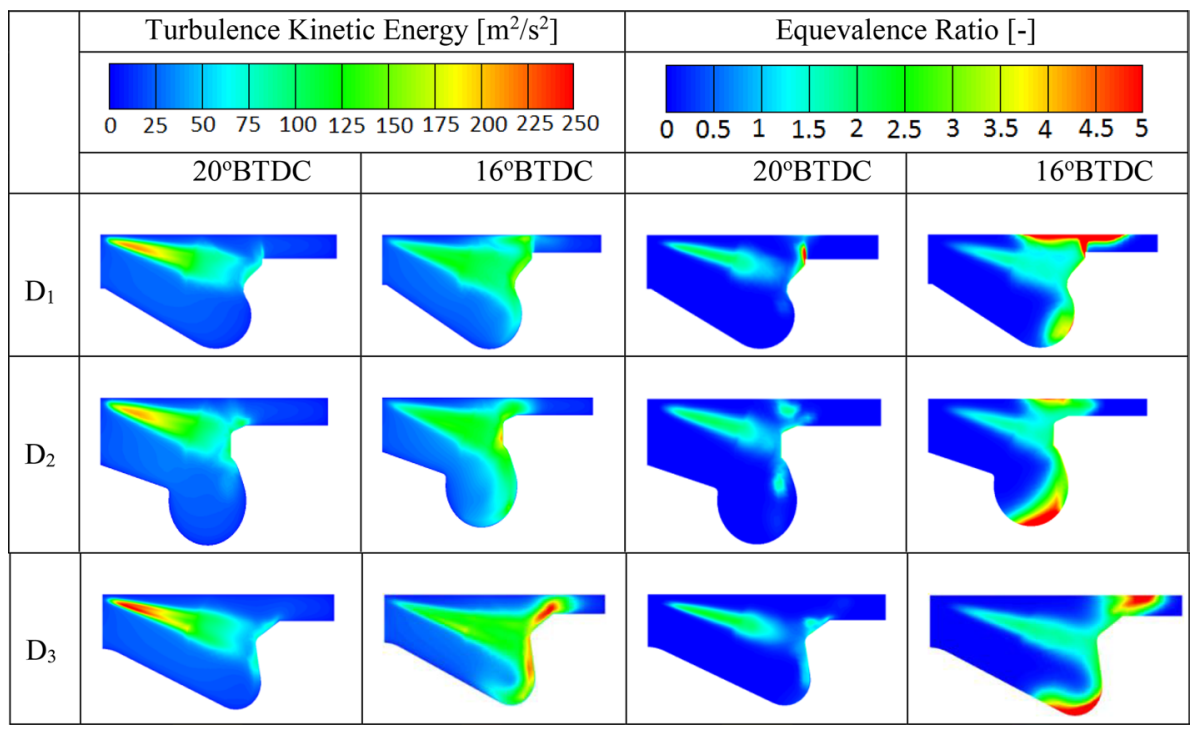




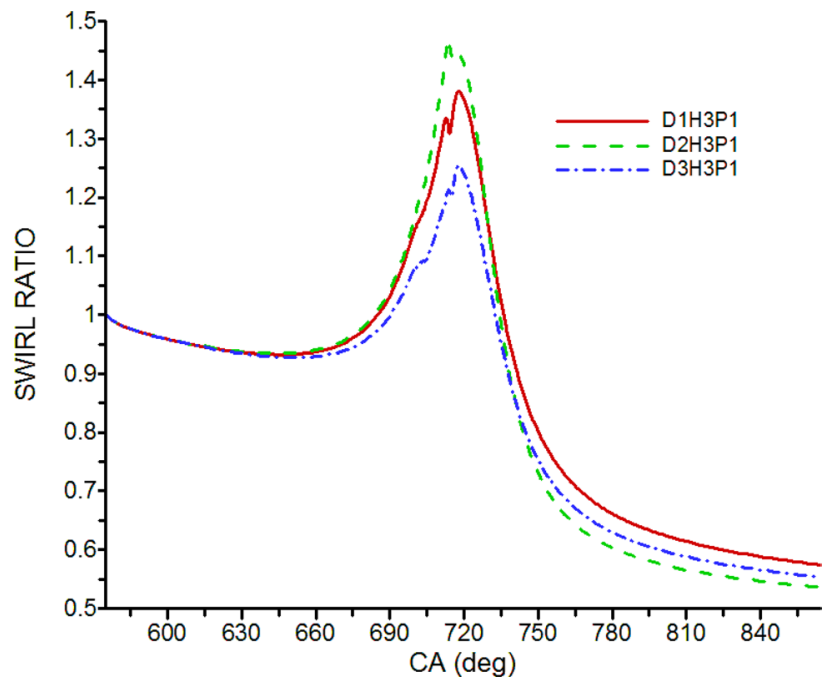

Fig. 7 Variation of swirl number with CA for different piston bowl geometry

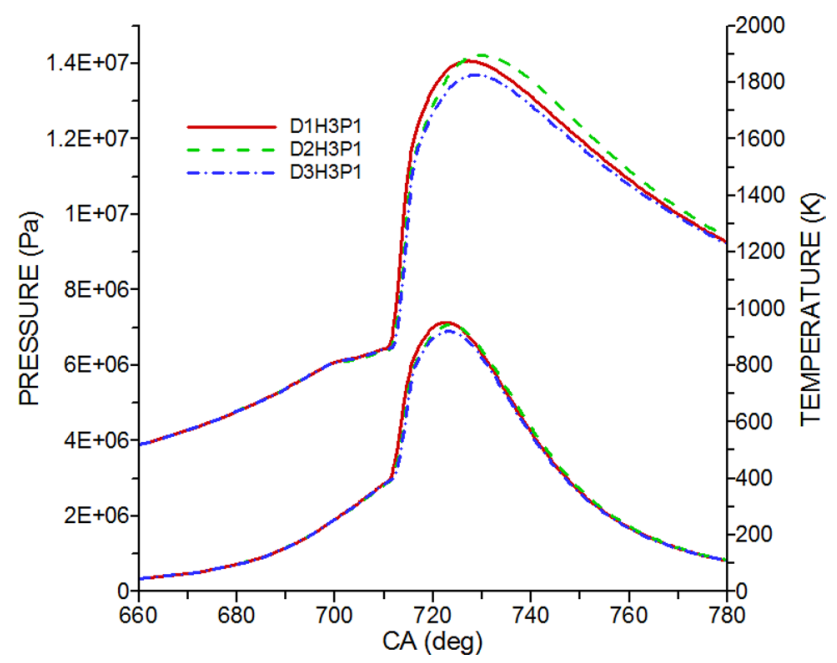

Fig. 8 Pressure and temperature for different piston bowl geometry

dissipation from walls is also high which decreases peak pressure into the combustion chamber. Figure 9 depicts the NO mass fraction variation with crank angle for different piston bowl geometries which is produced during combustion due to contained nitrogen and oxygen in air. It can be seen that the NO level at the end of the expansion stroke is minimum for $D_{2}$ and maximum for $D_{1}$. This may be attributed to the fact that NO mass fraction is temperature dependent; higher is temperature higher will be the $\mathrm{NO}$ emission. Figure 10 shows the $\mathrm{CO}$ mass variation with crank angle, which is minimum for piston bowl $D_{2}$ and maximum for $D_{3}$ at the end of the expansion stroke. This may be caused by better combustion characteristics of this combustion chamber. Figures 11 and 12 show soot

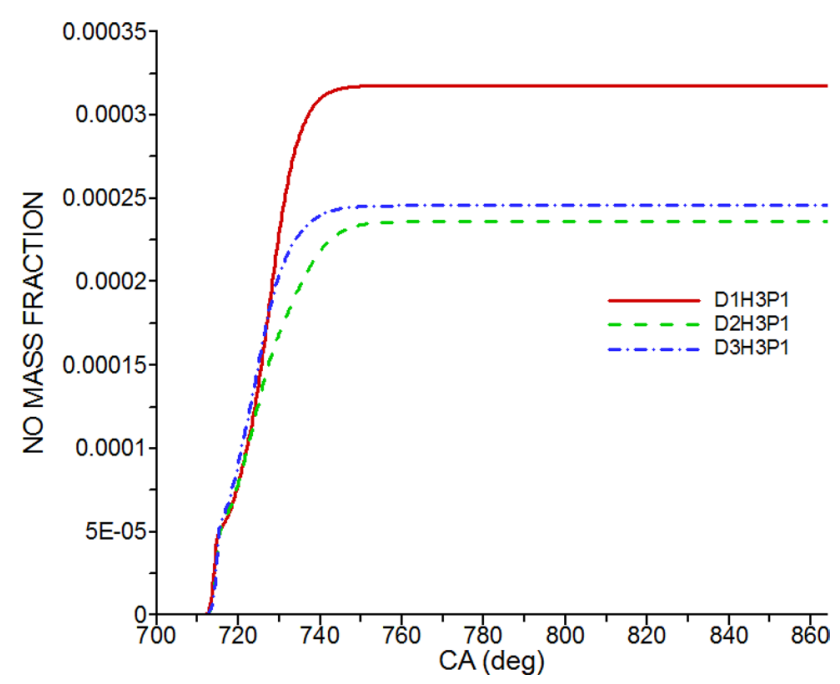

Fig. 9 NO mass fraction for different piston bowl geometry

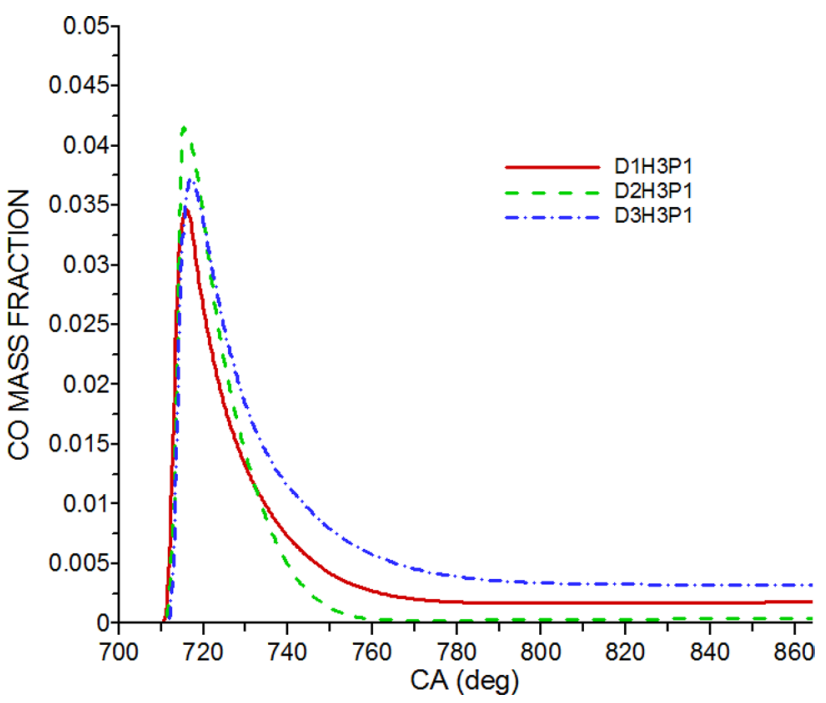

Fig. $10 \mathrm{CO}$ mass fraction for different piston bowl geometry

mass fraction variation and burnt fuel mass fraction with crank angle, respectively. It is observed that soot formation is higher for piston bowl geometry $D_{1}$. This may be attributed to over-rich mixture spot formation outside the bowl as well as lower TKE inside the bowl volume which also resulted in slow fuel burning rate. Soot formation is the lowest for piston bowl $D_{2}$ because of uniformity of mixture and higher turbulence inside the bowl. This also resulted in higher fuel burning rate.

\subsection{Effect of fuel injection pressure}

To analyse the effect of fuel injection pressure, three fuel injection pressures is considered with the same piston 


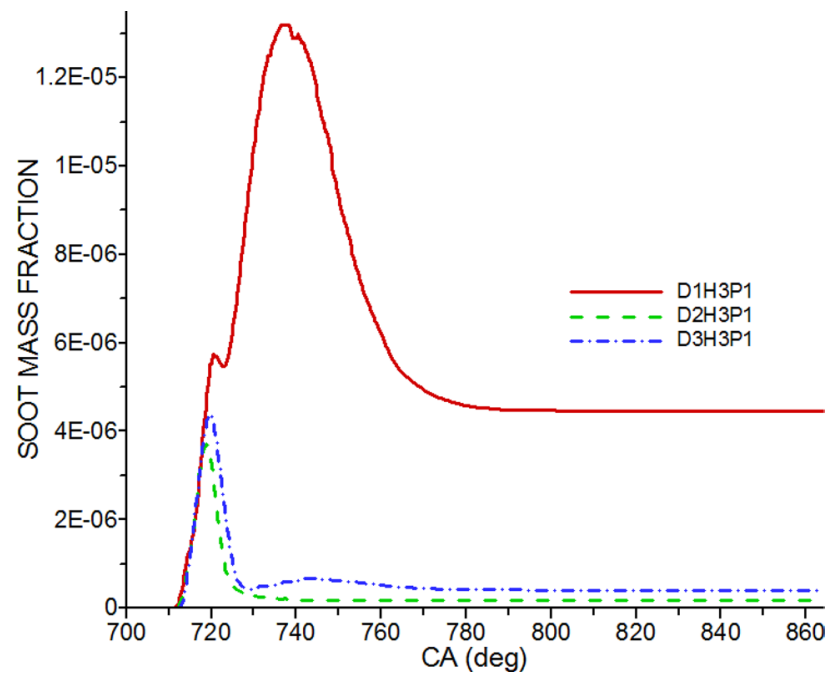

Fig. 11 SOOT mass fraction for different piston bowl geometry

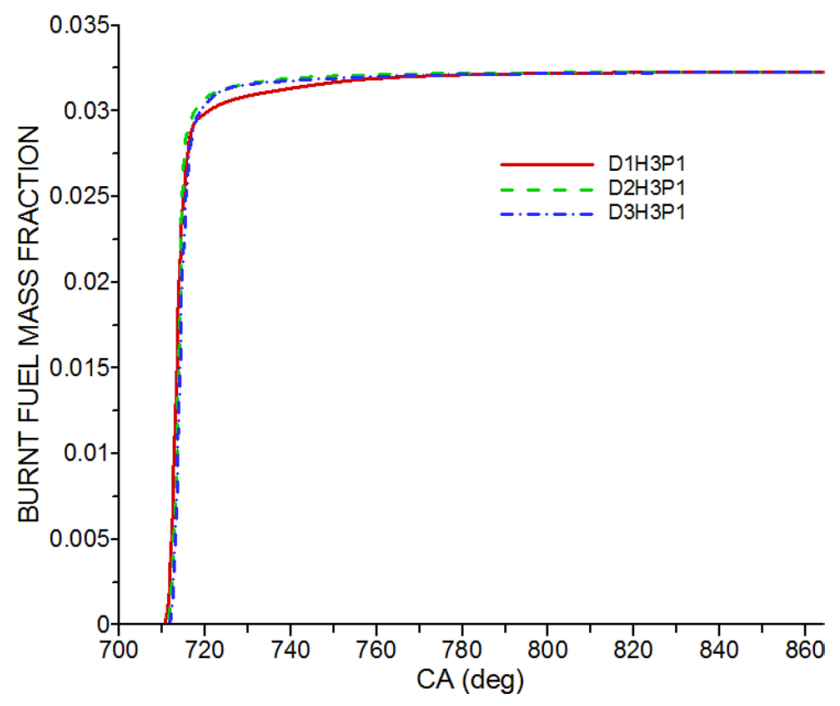

Fig. 12 Burnt fuel mass fraction for different piston bowl geometry

bowl geometry and nozzle outlet diameter. As the fuel injection pressure increases injection duration decreases due to increment in fuel injection velocity into the combustion chamber. TKE is surely get affected by fuel injection pressure, Fig. 13 depicts that as fuel injection pressure increases turbulent kinetic energy increases. $P_{1}$ and $P_{3}$ case have minimum and maximum values of TKE, respectively. The equivalence ratio is also getting better by increasing fuel injection pressure this is because atomization of fuel particle is getting improved by increase in fuel injection pressure as we can see in Fig. 13. Figure 14 shows the swirl ratio with crank angle. Fuel injection pressure does not affect swirl magnitude much, it slightly affects swirl at TDC due to the higher fuel injection rate. These effects lead to better combustion, and heat release rate got increases with fuel injection pressure due to this pressure and temperature get increases at a higher rate as the combustion take place. Figure 15 shows pressure and temperature variation with crank angle. $P_{1}$ have minimum pressure and temperature, and $P_{3}$ have maximum pressure and temperature. NO mass fraction is increases with increase in fuel injection pressure because the temperature of combustion chamber is increased. Figure 16 shows NO formation maximum for the case $P_{3}$ and minimum for $P_{1}$. CO mass fraction decrement rate after reaching peak value is higher for case $P_{3}$ and lower for $P_{1}$ as shown in Fig. 17 and gives minimum value for $P_{3}$ at the end of the expansion stroke. Figures 18 and 19 clearly show that soot formation is reduced with increase in fuel injection pressure owing to higher burning rate of fuel.

\subsection{Effect of nozzle diameter}

To analyse the effect of nozzle diameter, three nozzle outlet diameters are considered with same piston bowl geometry and fuel injection pressure. As nozzle diameter increases, fuel injection duration is decreases. Here the cause of injection duration decrement is increased area of flow for the fuel into the combustion chamber. TKE is affected due to fuel injection rate and because of this TKE is high with greater nozzle outlet diameter as shown in Fig. 20. TKE is minimum for $H_{1}$ and maximum for $\mathrm{H}_{3}$ also equivalence ratio is higher for greater nozzle outlet diameter which leads to a high combustion rate. Figure 20 shows maximum equivalence ratio for $\mathrm{H}_{3}$ and minimum for $H_{1}$. Figure 21 shows swirl ratio variation with crank angle for different nozzle outlet diameters. It can be seen that influence of nozzle outlet diameter on swirl ratio is not significant, however, it slightly affects swirl ratio at TDC. This may be due to variation of fuel injection rate with nozzle outlet diameter. Figure 22 depicts variation of pressure and temperature with crank angle for different nozzle outlet diameters. It can be seen that as the heat release rate increases with increasing nozzle outlet diameter which in turn increases the peak value of pressure and temperature. $H_{1}$ and $H_{3}$ show the lowest and highest value for pressure and temperature inside the combustion chamber, respectively. Because of temperature increment, NO formation increases with nozzle outlet diameter as we can see in Fig. 23; NO mass fraction is maximum for $\mathrm{H}_{3}$ and minimum for $H_{1}$. In the case of $\mathrm{CO}$ mass fraction, $\mathrm{CO}$ level increases rapidly as combustion takes place and have the highest peak for $\mathrm{H}_{3}$ as shown in Fig. 24 After attainment of peak value, it decreases, and decrement rate is higher for $\mathrm{H}_{3}$ which gives minimum value to $H_{3}$ at the end of combustion because of higher swirl 


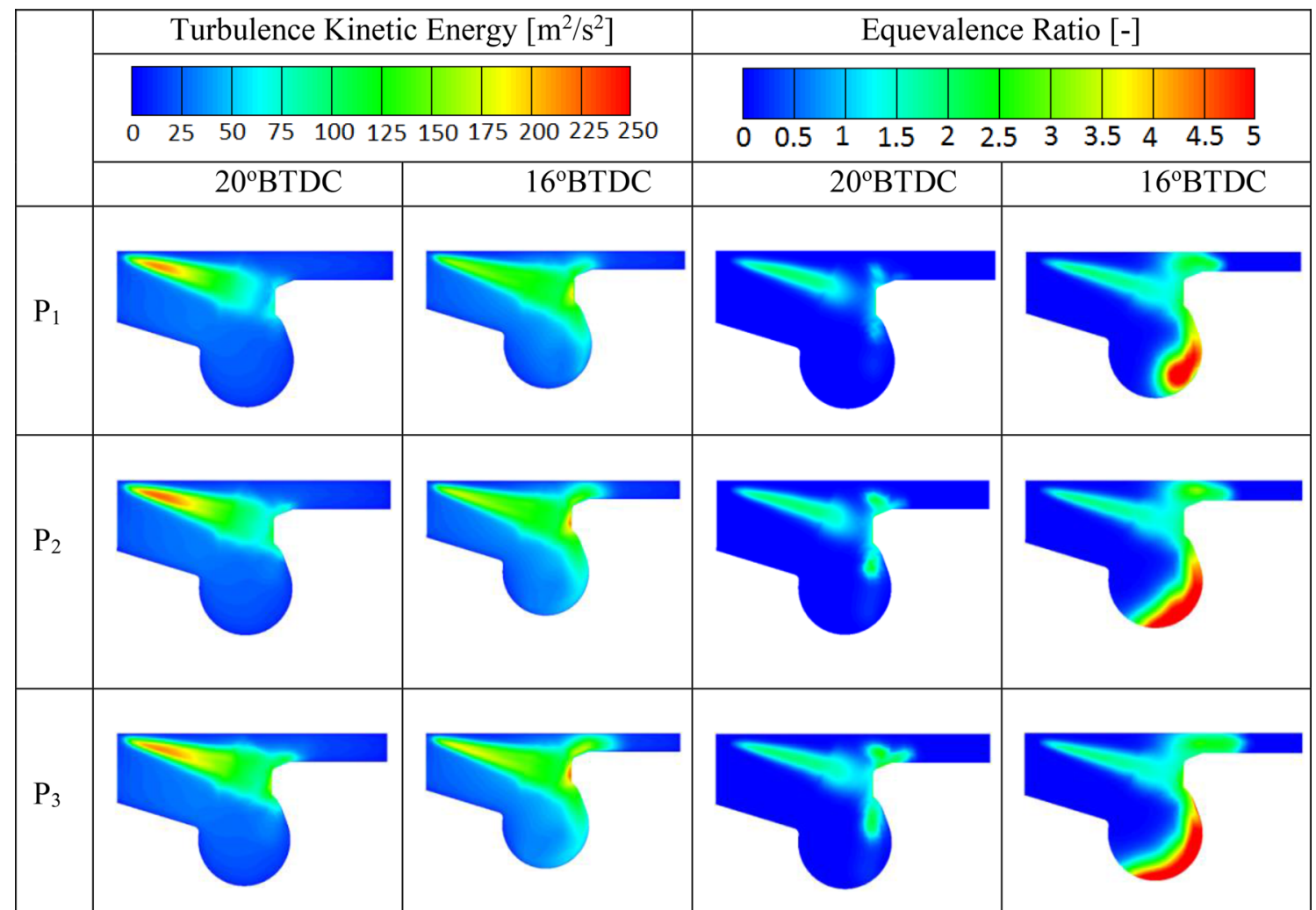

Fig. 13 Comparison between various fuel injection pressures in terms of turbulence kinetic energy and equivalence ratio

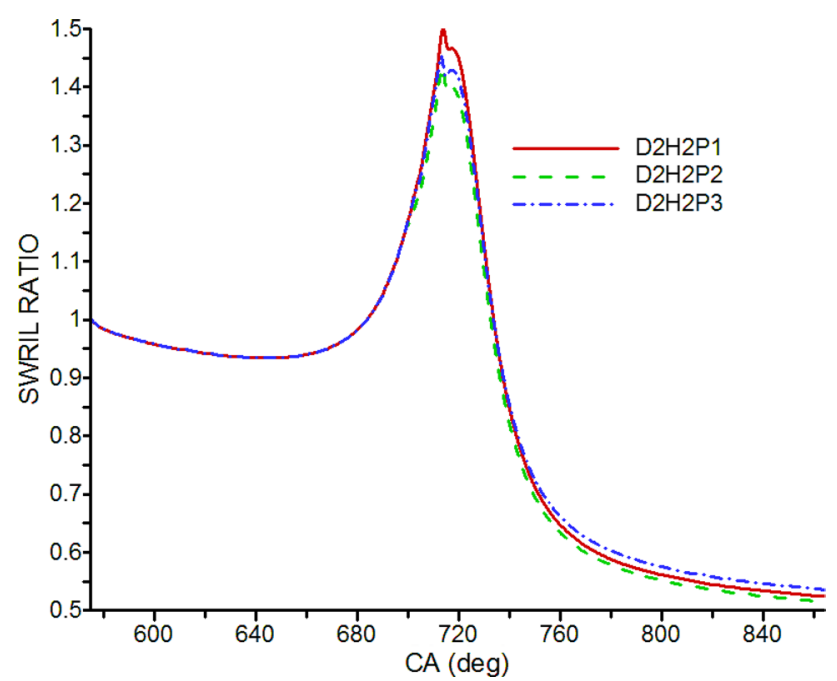

Fig. 14 Variation of swirl number with CA for different fuel injection pressure

magnitude at the end of the expansion stroke. Figure 25 depicts soot mass fraction variation with crank angle for nozzle outlet diameter; soot formation appeared to decrease with increase in nozzle outlet diameter. At the end of the expansion stroke, soot mass fraction

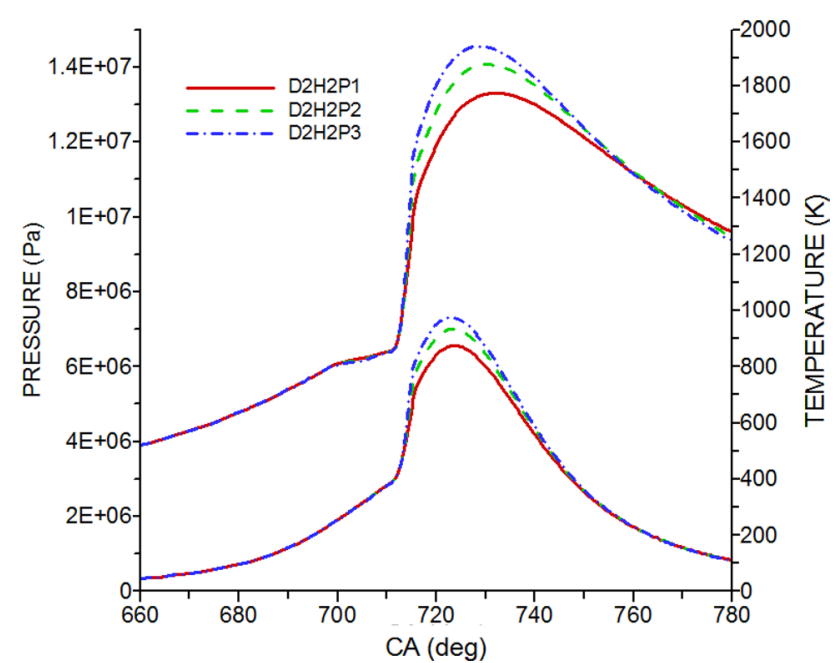

Fig. 15 Pressure and temperature for different fuel injection pressure

maximum for $H_{1}$ and minimum for $H_{3}$. Figure 26 shows that the burnt fuel mass fraction is increases with a nozzle outlet diameter. 


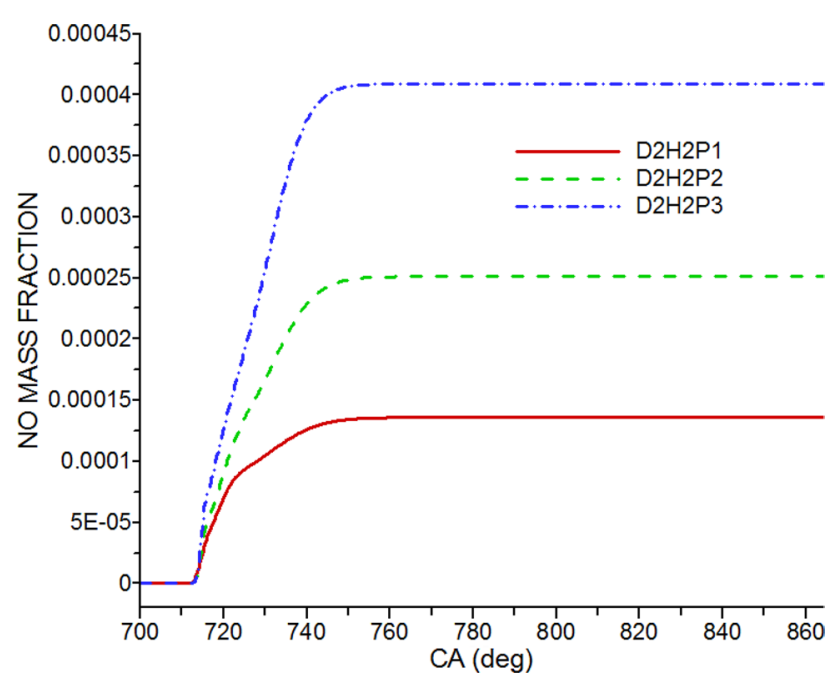

Fig. 16 NO mass fraction for different fuel injection pressure

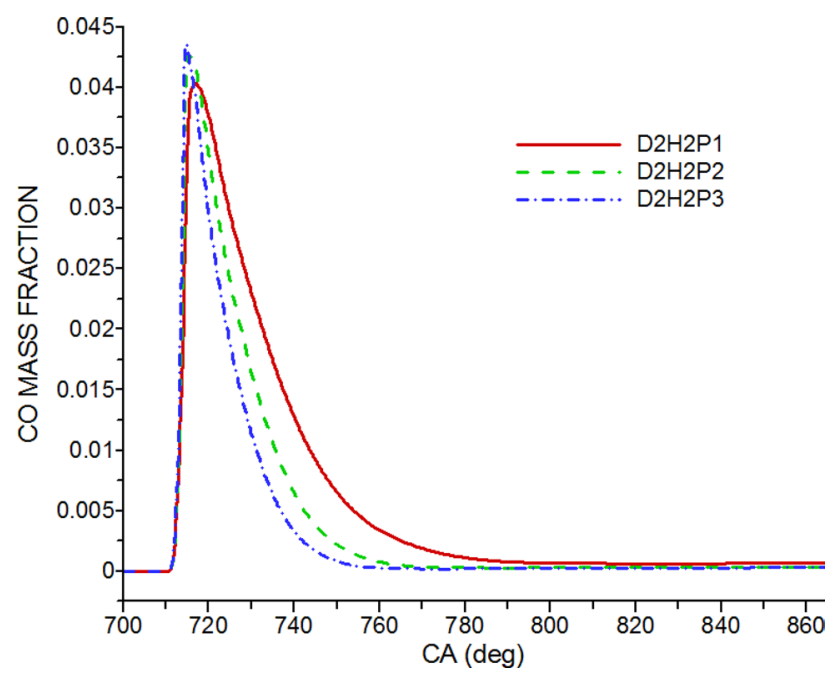

Fig. 17 CO mass fraction for different fuel injection pressure

\section{Optimization}

After the discussion of results, an optimization study is being done on above twenty-seven cases to find an optimum case.Fig. 27 shows $\mathrm{CO}$ and soot are plotted against the NO mass fraction for all cases. $D_{3} H_{1} P_{1}$ is taken as the reference case. Further ten cases are taken for comparison which is having minimum emission whose results are shown in Table 7. Taking emission as priority $D_{2} H_{1} P_{1}$ is an optimum case as we can see in Fig. 30 . Figures 28 , 29 and 30 show that $\mathrm{CO}, \mathrm{NO}$ and soot emission reduced by $57.108 \%, 62.299 \%$ and $57.807 \%$, respectively, while BSFC decreases by $3.136 \%$. However, from a performance point of view $\mathrm{D}_{2} \mathrm{H}_{2} \mathrm{P}_{2}$ may be considered as an

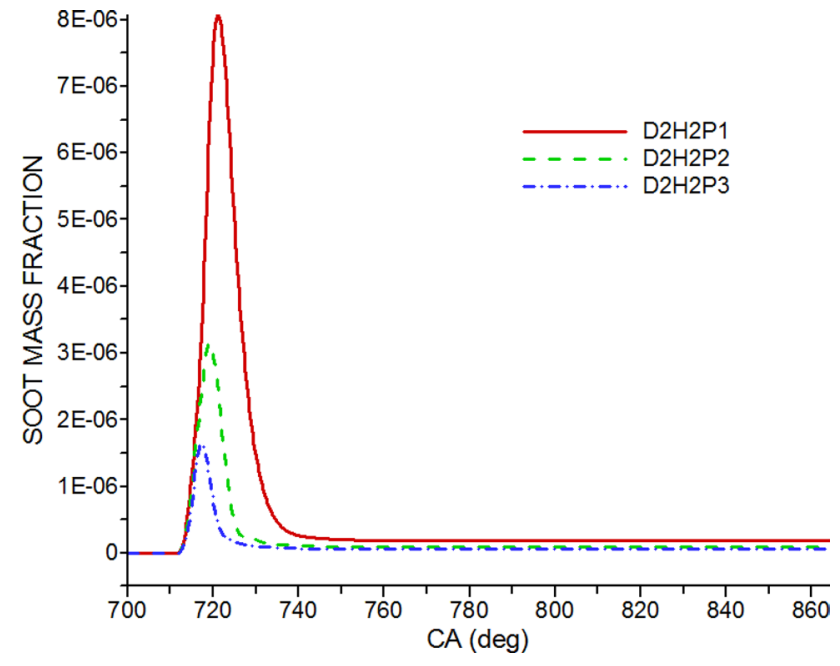

Fig. 18 SOOT mass fraction for different fuel injection pressure

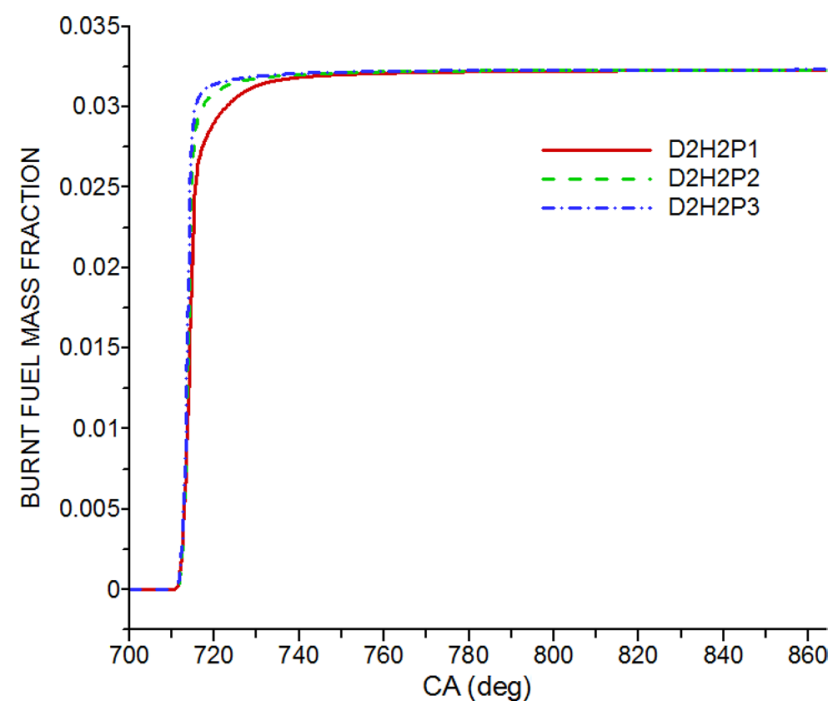

Fig. 19 Burnt fuel mass fraction for different fuel injection pressure

alternate case. In this case, an increase of $6.3872 \%$ and $23.0392 \%$ is noted in IMEP and NO, respectively, while CO, soot and BSFC decreased by $84.0347 \%, 91.6052 \%$ and $7.622 \%$, respectively. Increase in NO mass fraction can be controlled by proper handling of exhaust gases by after-treatment method.

\section{Conclusion}

In the present work, the combined effects of fuel injection pressure, injection nozzle size and piston bowl geometry on emission characteristics and thermal performance of a compression ignition engine were investigated. The 


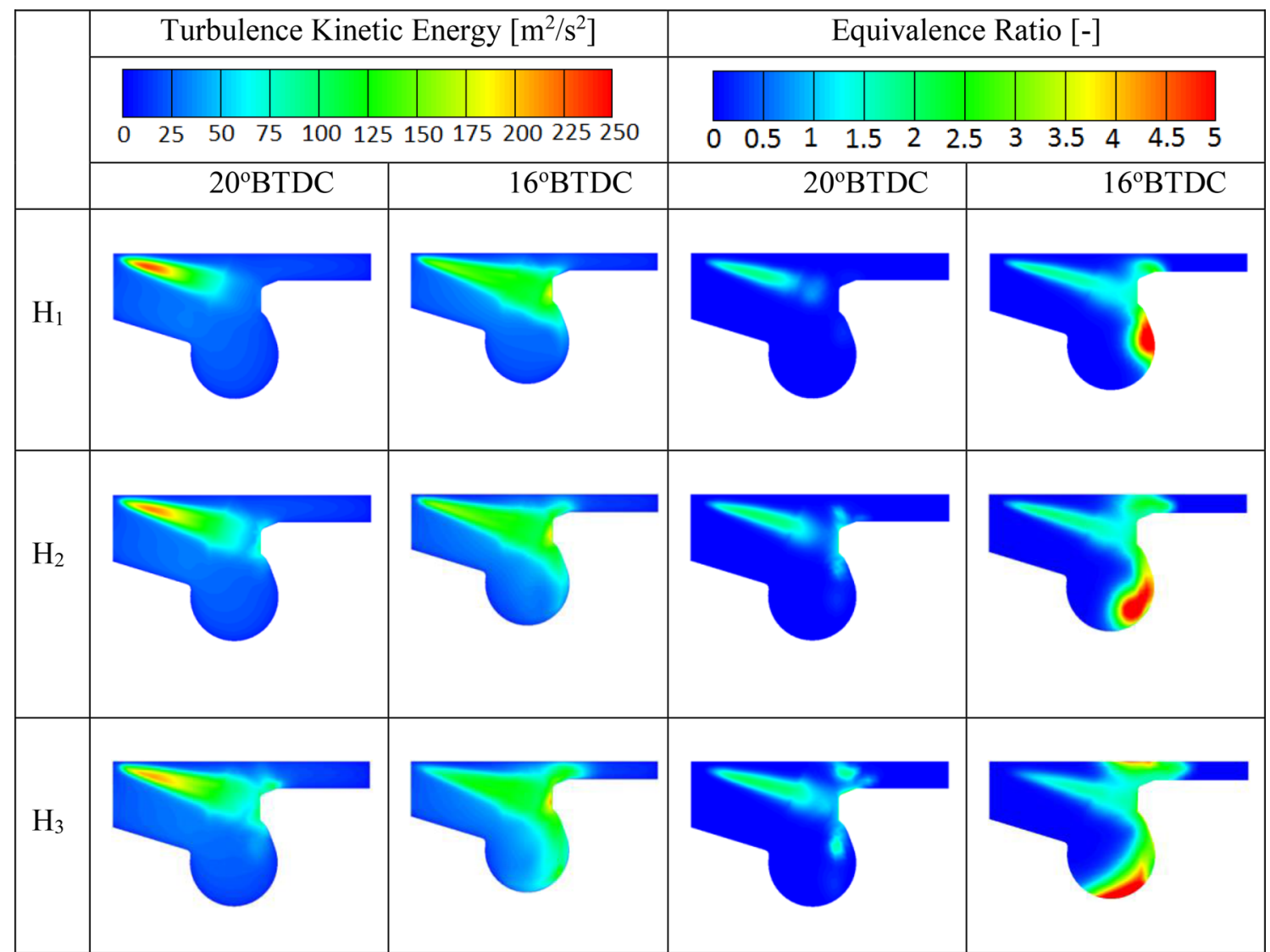

Fig. 20 Comparison between various nozzle outlet diameters in terms of turbulence kinetic energy and equivalence ratio

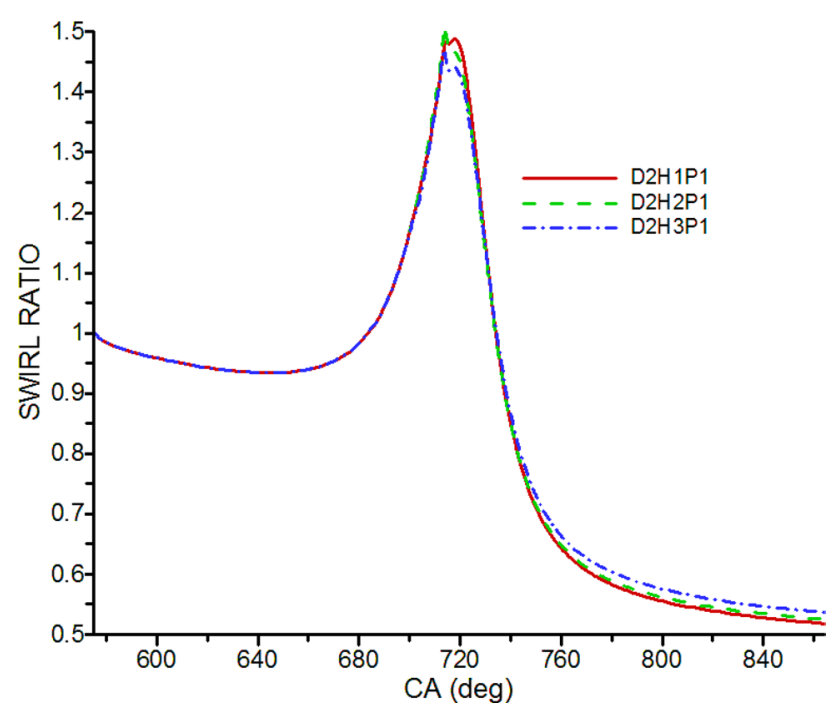

Fig. 21 Variation of swirl number with CA for different nozzle outlet diameter

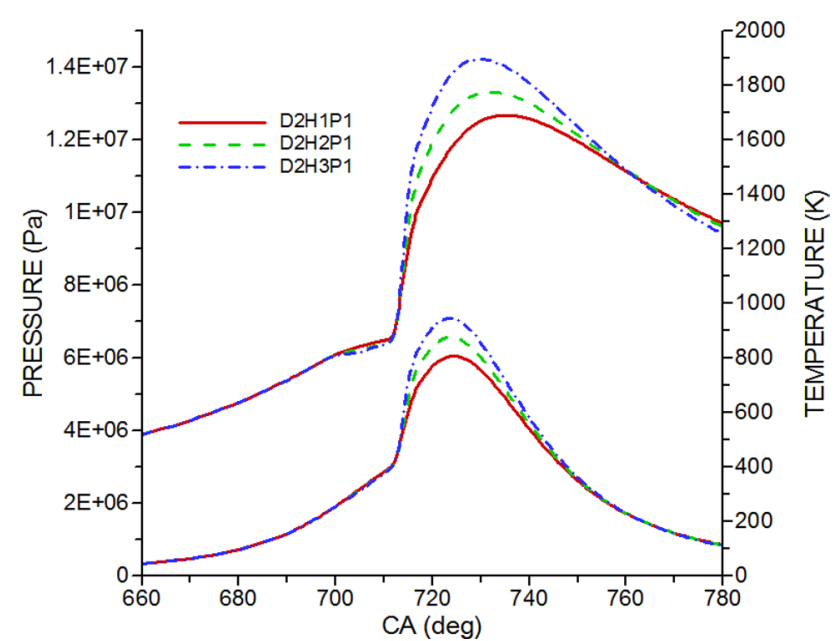

Fig. 22 Pressure and temperature for different nozzle outlet diameter 


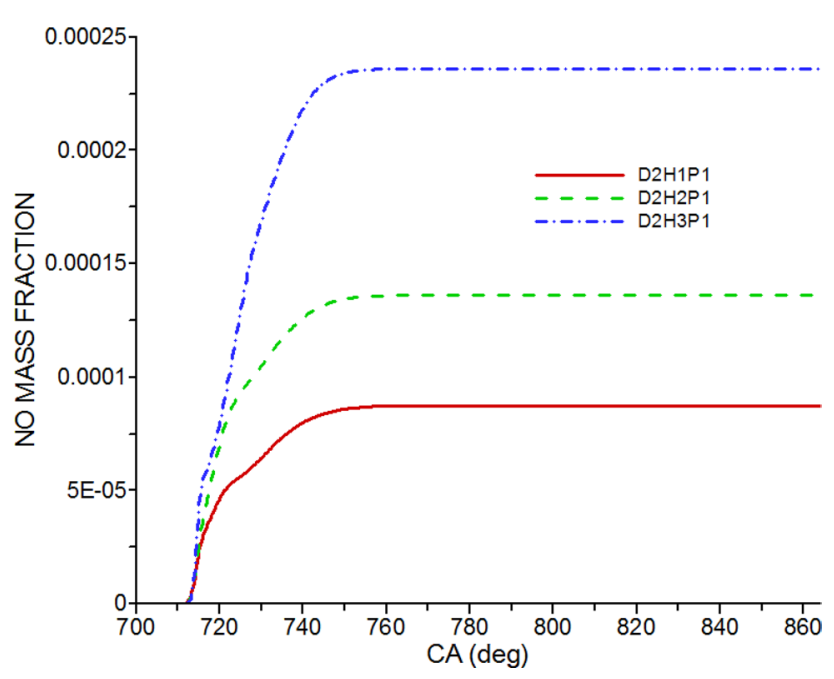

Fig. 23 NO mass fraction for different nozzle outlet diameter

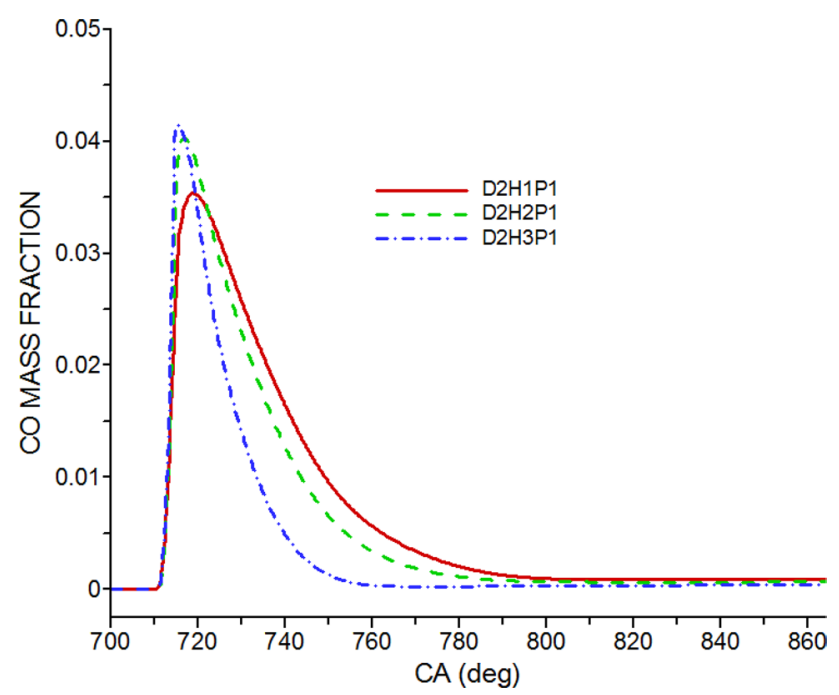

Fig. 24 CO mass fraction for different nozzle outlet diameter

conclusions drawn from the present research are encapsulated as follows:

1. Swirl and TKE tend to increase with increasing depth of piston bowl geometry during upward movement of the piston up to TDC. However after TDC, swirl takes a sharp downhill trend while TKE remains almost invariant till the end of the expansion stroke. Further, NO is high for higher piston depth.

2. With increasing fuel injection pressure, TKE and equivalence ratio increases during fuel injection period leading to better combustion and, hence, reducing the soot formation and increasing $\mathrm{NO}_{\mathrm{x}}$ emission.

3. Increase in nozzle outlet diameter reduces the duration of fuel injection. TKE and equivalence ratio are

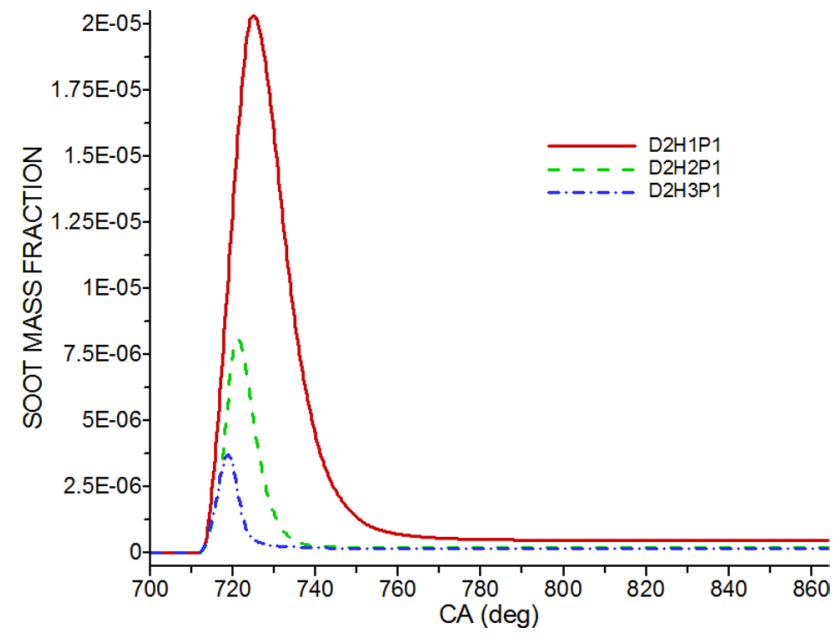

Fig. 25 SOOT mass fraction for different nozzle outlet diameter

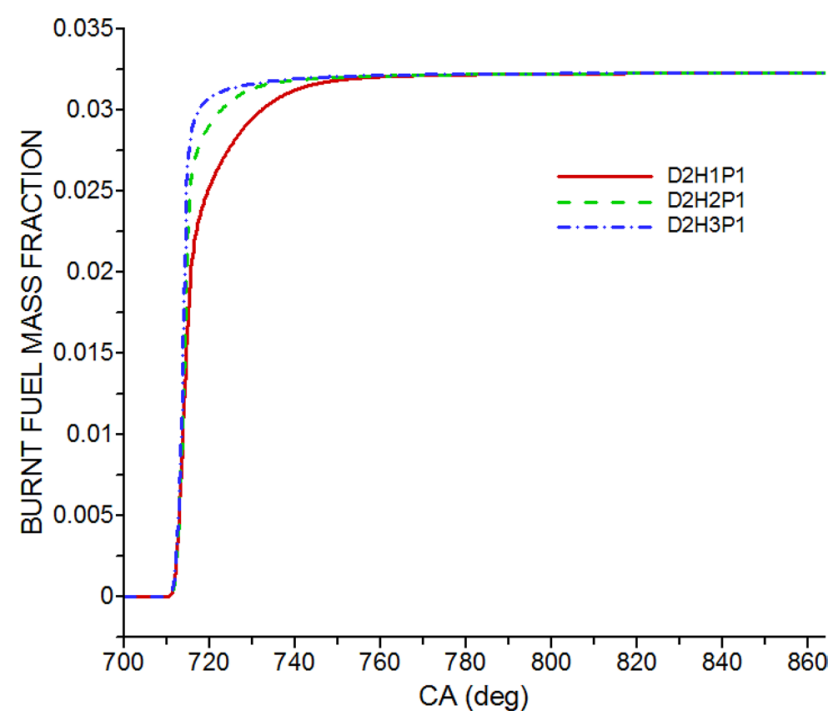

Fig. 26 Burnt fuel mass fraction for different nozzle outlet diameter

high for higher nozzle outlet diameter. $\mathrm{NO}_{\mathrm{x}}$ emission increases with increasing nozzle outlet diameter while soot formation decreases due to higher combustion rate.

4. Amongst twenty-seven cases analysed, $D_{2} H_{1} P_{1}$ is found to be optimum in view of low emission. However, $D_{2} H_{2} P_{2}$ may be considered as an alternate case from the performance point of view. Higher $\mathrm{NO}_{x}$ level in this case can be minimised by using an appropriate aftertreatment. 


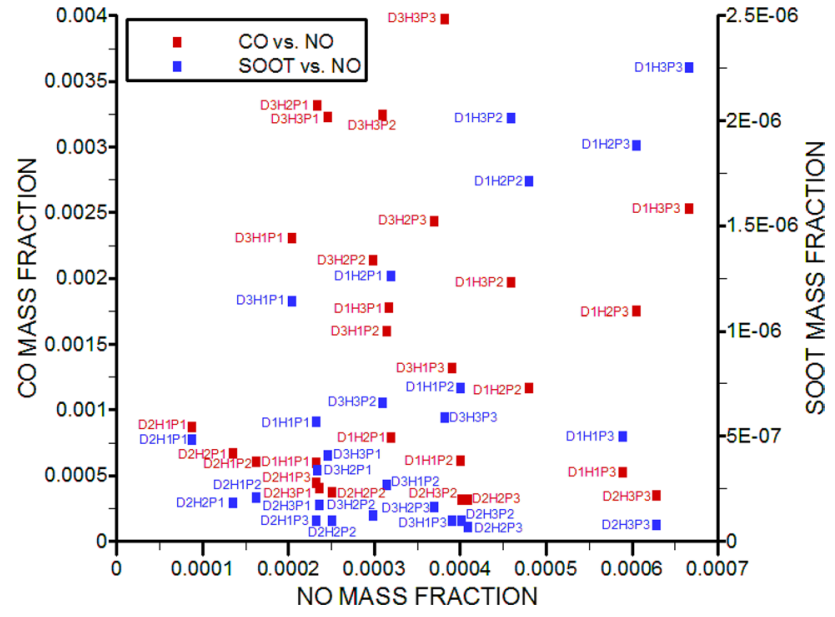

Fig. $27 \mathrm{CO}$ and soot versus NO mass fraction for all cases

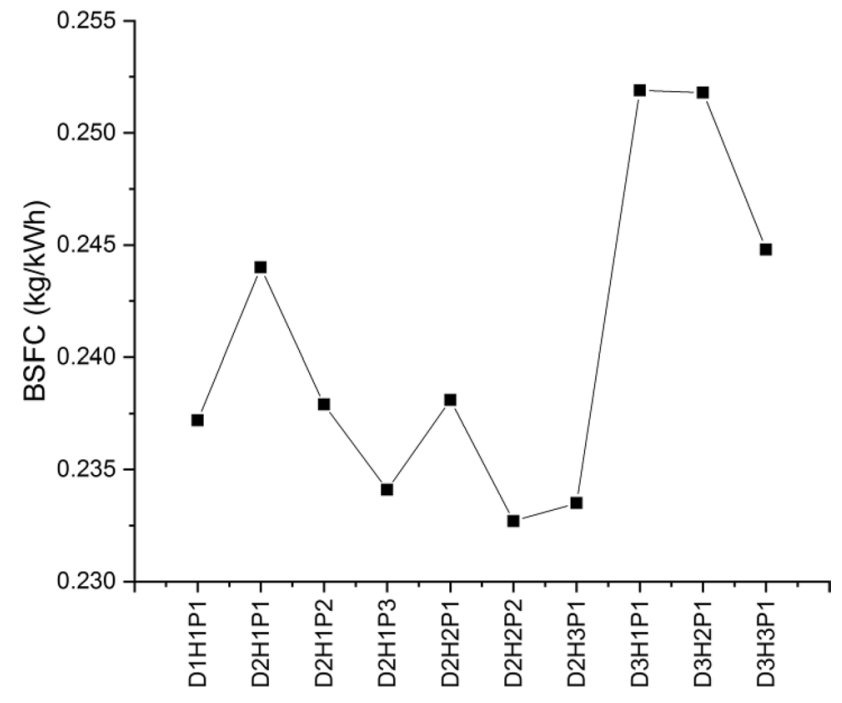

Fig. 29 BSFC for the selected ten cases

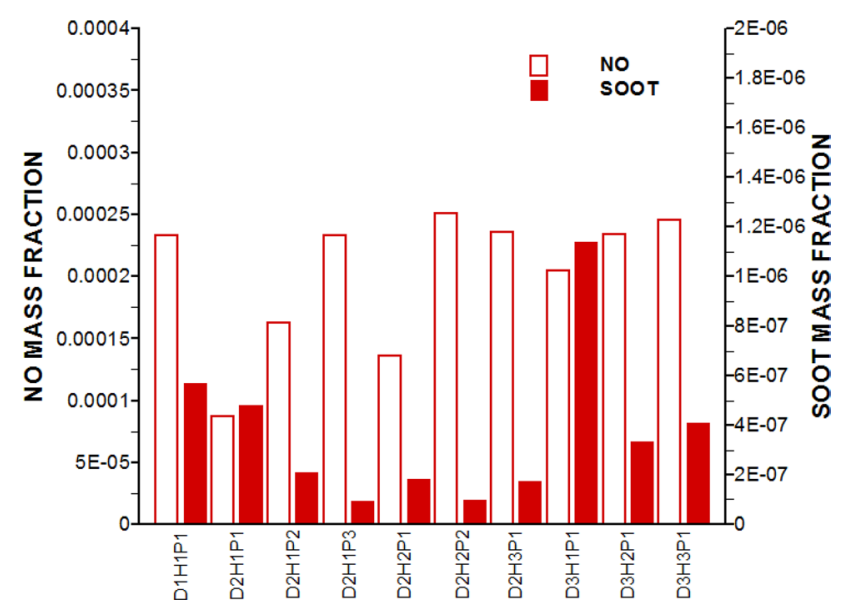

Fig. 30 Soot and NO mass fraction for the selected ten cases

\section{Future scope of work}

This work can be further extended by taking crevice volume which is the volume between piston and the cylinder liner, in to account since it can affect the emission as well as the engine performance significantly owing to fuel getting trapped into it. Effect of load and speed variation may be investigated since they affect the actual engine performance.

Acknowledgements This research was supported by the mechanical engineering department at Maulana Azad National Institute of Technology, Bhopal.

Funding This research did not receive any specific grant from funding agencies in the public, commercial or not-for-profit sectors.

Fig. 28 IMEP for the selected ten cases 


\section{Declarations}

Conflict of interest The authors declare that they have no conflict of interest.

Open Access This article is licensed under a Creative Commons Attribution 4.0 International License, which permits use, sharing, adaptation, distribution and reproduction in any medium or format, as long as you give appropriate credit to the original author(s) and the source, provide a link to the Creative Commons licence, and indicate if changes were made. The images or other third party material in this article are included in the article's Creative Commons licence, unless indicated otherwise in a credit line to the material. If material is not included in the article's Creative Commons licence and your intended use is not permitted by statutory regulation or exceeds the permitted use, you will need to obtain permission directly from the copyright holder. To view a copy of this licence, visit http://creativecommons. org/licenses/by/4.0/.

\section{References}

1. Höök M, Tang X (2013) Depletion of fossil fuels and anthropogenic climate change-a review. Energy Policy 52:797-809

2. Gafoor CPA, Gupta R (2015) Numerical investigation of piston bowl geometry and swirl ratio on emission from diesel engines. Energy Convers Manag 101:541-551

3. Jafarmadar S, Taghavifar H, Taghavifar H, Navid A (2016) Numerical assessment of flow dynamics for various DI diesel engine designs considering swirl number and uniformity index. Energy Convers Manag 110:347-355

4. Corcicone E, Fusco A, Valentino G (1993) Numerical and experimental analysis of air fuel mixing. SAE, 931948

5. Montajir M, Tsunemoto H, Ishitani H, Minami T (2000) Fuel spray behavior in a small DI diesel engine: effect of combustion chamber geometry. SAE, 2000-01-0946

6. Khan S, Panua R, Bose PK (2018) Combined effects of piston bowl geometry and spray pattern on mixing, combustion and emissions of a diesel engine: a numerical approach. Fuel 225:203-217

7. Risi A, Donateo T, Laforgia D (2003) Optimization of the combustion chamber of direct injection diesel engines. SAE, 2003-01-1064

8. Rakopoulos CD, Kosmadakis GM, Pariotis EG (2010) Investigation of piston bowl geometry and speed effects in a motored HSDI diesel engine using a CFD against a quasi-dimensional model. Energy Convers Manag 51:470-484

9. Lim J, Min K (2005) The effects of spray angle and piston bowl shape on diesel engine soot emissions using 3-D CFD simulation. SAE, 2005-01-2117

10. Wei S, Wang F, Leng X, Liu X, Ji K (2013) Numerical analysis on the effect of swirl ratios on the swirl chamber combustion system of DI diesel engines. Energy Convers Manag 75:184-190

11. Gan S, Kiat NH, Mun PK (2011) Homogeneous charge compression ignition $(\mathrm{HCCl})$ combustion: implementation and effects on pollutants in direct injection diesel engines. Appl Energy 88:559-567

12. Perini F, Miles Paul C, Reitz RD (2014) A comprehensive modeling study of in-cylinder fluid flows in a high-swirl, light-duty optical diesel engine. Comput Fluids 105:113-124

13. Torregrosa AJ, Broatch A, García A, Mónico LF (2013) Sensitivity of combustion noise and $\mathrm{NO}_{x}$ and soot emissions to pilot injection in PCCl diesel engines. Appl Energy 104:149-157
14. Benajes J, López JJ, Novella R, Redón P (2014) Comprehensive modeling study analyzing the insights of the $\mathrm{NO}-\mathrm{NO}_{2}$ conversion process in current diesel engines. Energy Convers Manag 84:691-700

15. Jayashankara B, Ganesan V (2010) Effect of fuel injection timing and intake pressure on the performance of a DI diesel engine-a parametric study using CFD. Energy Convers Manag 51:1835-1848

16. Abedin MJ, Masjuki HH, Kalam MA, Sanjid A, Ashraful AM (2014) Combustion, performance, and emission characteristics of low heat rejection engine operating on various biodiesels and vegetable oils. Energy Convers Manag 85:173-189

17. Ozer C (2014) Combustion characteristics, performance and exhaust emissions of a diesel engine fueled with a waste cooking oil biodiesel mixture. Energy Convers Manag 87:676-686

18. Chandran M, Tamilkolundu S, Murugesan C (2020) Numerical simulation of diesel engine using waste plastic oil blends. SN Appl Sci 2:1610

19. Kumar P, Kumar S, Shah S et al (2021) Study of performance parameters and emissions of four stroke $\mathrm{Cl}$ engine using solketal-biodiesel blends. SN Appl Sci 3:59

20. Kumar CB, Lata DB, Mahto D (2021) Effect of addition of di-tert butyl peroxide (DTBP) on performance and exhaust emissions of dual fuel diesel engine with hydrogen as a secondary fuel. Int J Hydrog Energy 46:9595-9612

21. Hemanandh J, Devarajan Y, Mishra R et al (2021) Experimental investigation on slaughter, fish waste and poultry excrete oil as fuel blends in diesel engine. Biomass Conv Bioref 11:1-9

22. Viswanathan K, Wang S (2021) Experimental investigation on the application of preheated fish oil ethyl ester as a fuel in diesel engine. Fuel 285:119244

23. Jaichandar S, Annamalai K (2013) Combined impact of injection pressure and combustion chamber geometry on the performance of a biodiesel-fueled diesel engine. Energy 55:330-339

24. Agarwal AK, Dhar A, Gupta JG, Kim WI, Lee CS, Park S (2014) Effect of fuel injection pressure and injection timing on spray characteristics and particulate size-number distribution in a biodiesel fuelled common rail direct injection diesel engine. Appl Energy 130:212-221

25. Chinnamuthu N, Ganapathy SC, Malaiperumal V et al (2020) Computational analysis of turbulence enhancement in a compression ignition engine with modified inlet design. Environ Sci Pollut Res 27:1-14

26. Fayad MA (2019) Effect of fuel injection strategy on combustion performance and $\mathrm{NO}_{\mathrm{x}}$ /smoke trade-off under a range of operating conditions for a heavy-duty DI diesel engine. SN Appl Sci $1: 1088$

27. Kesharwani A, Gupta R (2020) Evaluation of performance and emission characteristics of a diesel engine using split injection. J Braz Soc Mech Sci Eng 42:331

28. Wang $Y, M a T$, Liu L, Yao M (2021) Numerical investigation of the effect of thermal barrier coating on combustion and emissions in a diesel engine. Appl Therm Eng 186:116497

29. Hanjalic K, Popovac M, Hadziabdic M (2004) A robust near-wall elliptic-relaxation eddy-viscosity turbulence model for CFD. Int J Heat Fluid Flow 25:1047-1051

30. Uludogan A, Foster DE, Reitz RD (1996) Modeling the effect of engine speed on the combustion process and emissions in a DI diesel engine. SAE pap, 962056

31. Lui AB, Mather D, Reitz RD (1993) Modeling the effect of drop drag and break of fuel sprays. SAE paper, 930072

32. Dukowicz JK (1980) A particle-fluid numerical model for liquid sprays. J Comput Phys 35:229-253

33. Colin O, Benkenida A (2004) The 3-zones extended coherent flame model (ECFM3Z) for computing premixed/diffusion combustion. Oil Gas Sci Technol Rev IFP 59:593-609 
34. Zeldovich YB, Sadovnikov PY, Frank Kamenetskii DA (1947) Oxidation of nitrogen in combustion, Translated by M. Shelef, Academy of science of USSR, Institute of Chemical Physics, Moscow-Leningrad

35. Mauss F, Magnusson I, Balthasar M, Karlsson A (1998) Simulation of soot formation under diesel engine conditions using detailed kinetic soot model. SAE, 981022

36. Tatschl R, Priesching P, Ruetz J (2007) Recent advances in DIdiesel combustion modeling in AVL FIRE-a validation. In:
International multidimensional engine modeling user's group meeting at the SAE congress, Detroit, MI

Publisher's Note Springer Nature remains neutral with regard to jurisdictional claims in published maps and institutional affiliations. 